\title{
REVIEW
}

\section{Trophic biology of antarctic shallow-water echinoderms}

\author{
James B. McClintock \\ Department of Biology, The University of Alabama at Birmingham, Birmingham, Alabama 35294-1170, USA
}

\begin{abstract}
Antarctic echinoderms appear to be adapted to a benthic environment characterized by long-term low availability of food resources. As predicted for a low-energy system, most echinoderms appear to expend little energy on feeding. Moreover, they are primarily generalists which opportunistically display scavenging or necrophagous feeding habits. Others exploit detrital material, or ingest microorganisms from the benthos and plankton. Those echinoderms which are feeding specialists exploit prey which are low in energy content yet extremely abundant, such as sponges. Even though individuals may have a low energy intake, it is likely that echinoderms play a significant role in energy transfer in antarctic benthos, as they are among the most abundant of epibenthic macroinvertebrate groups in shallow antarctic seas.
\end{abstract}

KEY WORDS: Antarctica - Echinoderm - Trophic biology

\section{INTRODUCTION}

The antarctic benthic environment is unique in many respects. Cumulatively its characteristics might be expected to have influenced the evolution of feeding strategies in antarctic echinoderms. Perhaps the most commonly considered physical factor of the antarctic marine environment is sea water temperature, which varies seasonally only from -1.5 to $-2.0^{\circ} \mathrm{C}$ in shallow antarctic waters, while attaining slightly higher temperatures along the Antarctic Peninsula (Littlepage 1965). Because of the extreme geological age of the antarctic system it is likely that ample time has been available for evolutionary adaptation to low temperature (Kinne 1963, Clarke 1983, Pearse et al. 1991). Feeding activities in antarctic echinoderms can therefore be expected to be temperature adapted (Lawrence \& McClintock in press). This is supported by studies demonstrating temperature acclimation in echinoderms from temperate and tropical latitudes (Lares \& McClintock 1991 and references within). Moreover, temperature adaptation can be inferred by acclimation in feeding rates of the boreal-arctic sea urchin Strongylocentrotus droebachiensis (Percy 1972, 1973, 1974, Vadas 1977, Himmelman 1984).

A second physical factor which is more likely than low temperature to influence feeding in antarctic echinoderms in shallow water is sea ice. In areas not under the permanent ice shelf, the dramatic impact of anchor ice and ice scour on shallow antarctic benthos has been well documented (Dayton et al. 1969, 1970, Dayton 1990). Echinoderms exploiting prey in these shallow waters would be expected to feed opportunistically on mobile prey, as sessile prey are rare or absent due to the activities of ice. Below $33 \mathrm{~m}$, the antarctic benthos is physically stable and dominated by sessile macroinvertebrates, particularly sponges (Koltun 1970 , Dayton 1979, 1990). Echinoderms exploiting prey at these depths, free of the effects of ice, have an opportunity to utilize either mobile or sessile prey. In contrast to the higher antarctic latitudes, the influence of ice in shallow subantarctic benthos can be expected to be reduced, allowing for exploitation of more predictable, less physically disturbed resources.

Perhaps the most likely factor to have influenced the evolution of feeding in antarctic echinoderms is nutri- 
ent availability. The antarctic oceans are considered oligotrophic, with very brief periods of high primary production occurring seasonally (Dunbar 1970, Knox 1970, Clarke 1983, Picken 1985). The antarctic marine environment may also be characterized as a stable habitat with long-term low availability of food resources, modified in geographic locations by predictable short-term primary production (Dunbar 1970, Knox 1970). Limited food availability has been implicated as the primary basis of low growth rates in many antarctic marine invertebrates (Clarke 1980, Brey \& Clarke 1993). Grime $(1977,1979)$ predicts that food gathering in unproductive environments should be conservative, and Lawrence \& McClintock (in press) suggest that antarctic echinoderms should allocate little energy to feeding (low-energy feeders). Moreover, low resource environments would be expected to select for feeding on a wide range of prey types or exploiting prey which are common most of the time (Valentine 1983). The following information provides an overview and synthesis of the current state of knowledge of the dietary habits and feeding strategies of antarctic echinoderms. Although nutrient constraints could be expected to similarly influence nutritional modes of antarctic echinoderm embryos and larvae (see Pearse et al. 1991 and references within), the present review focuses on adult echinoderms.

\section{Antarctic echinoderms as scavengers (necrophagous feeders), detritivores and planktivores}

Many antarctic echinoderms, including representatives of the asteroids, ophiuroids, echinoids and holothuroids, are classified as scavenging or necrophagous feeders. This is based, in part, on the use of traps baited with meat (primarily fish, seal and penguin) for the collection of echinoderms and other antarctic marine invertebrates and fish (e.g. Doderlein 1927, Pearse \& Giese 1966, Dearborn 1967, Arnaud 1970, 1974). Nonetheless, it is likely that antarctic echinoderms attracted to meat baits also locate and feed on naturally dead or dying organisms. One of the most abundant asteroids captured using meat bait is Odontaster validus (Clark 1963. Pearse \& Giese 1966, Hoshiai 1968, Arnaud 1970, 1974, Zamorano et al. 1986). This is probably a result of its high abundance, and omnivorous feeding habits (Dayton et al. 1974). Other antarctic asteroids which have necrophagous feeding habits include Psilaster charcoti, Acodontaster hodgsoni, $O$. meridionalis, Cuenotaster involutus, Perknaster densus, P. fuscus, Porania antarctica, Diplasterias brucei, Lyasterias perrieri. Neosmilaster georgianus and Saliasterias brachiata (Table 1). Among asteroids whose feeding habits have been examined in subantarctic latitudes, only Anasterias perri- eri has been collected using meat bait (Arnaud 1974). However, information on the feeding habits of subantarctic asteroids is limited.

A similar number of species of antarctic ophiuroids have been captured using meat baits (Table 1). Fell (1961) documented necrophagy in Astrotoma agassizil, Ophiurolepis gelida, O. martensi, Ophiacantha antarctica, O. vivipara and Ophiosteira echinulata. The large and extremely mobile ophiuroids Ophiosparte gigas and Ophionotus victoriae were captured using penguin meat by Arnaud $(1970,1974)$ at Adélie Land. Moreover, Numanami et al. (1984) captured 657 specimens $(59.7 \%$ of total catch representing 42 invertebrate species) of $O$. victoriae in baited traps in LützowHolm Bay. Three additional subantarctic ophiuroids, Ophionotus hexactis, Ophiocten ultimum and Amphiura joubini, display necrophagous feeding behaviors (Hertz 1927, Arnaud 1974).

Among echinoids and holothuroids, scavenging or necrophagous feeding habits have been observed in comparatively few species. The only antarctic echinoid observed scavenging meat is the common omnivorous regular echinid sea urchin Sterechinus neumayeri (Arnaud 1974). Cidaroid sea urchins generally have carnivorous habits (DeRidder \& Lawrence 1982). Four antarctic cidarid sea urchins, Austrocidaris caniculata, Aprocidaris milleri, Ctenocidaris perrieri and C. gilberti, have been suggested to be scavengers (Fell 1976), although they apparently feed on live prey as well. The feeding habits of most antarctic holothuroids have received little attention. Although Arnaud (1974) captured Psolus charcoti, Heterocucumis vaneyi, $\mathrm{H}$. denticulata, $H$. coatsi, and Hypsilocucumis turnicata using meat bait (Table 1), these species are likely suspension feeders as they share a taxonomic affinity with a suspension feeding group (Massin 1982). Gutt (1991) indicates that suspension feeding is the dominant feeding mode of antarctic holothurians in the Weddell Sea (20 of 32 species).

It is likely that necrophagy is an adaptation to a foodlimited environment. Arnaud $(1970,1974)$ proposed a positive correlation between the incidence of necrophagy in Antarctica and low sea water temperature. He notes that necrophagy is more common in antarctic asteroids, ophiuroids and holothuroids when compared with species from other latitudes and suggests that this may be related to an energy-efficient foraging strategy at low water temperature. Moreover, to support the hypothesis of a relationship between necrophagy and low water temperature, Arnaud suggests that the incidence of necrophagy in benthic marine invertebrates diminishes in warmer subantarctic waters. This may in fact represent an increase in availability of energy-rich prey in the subantarctic. Arnaud notes that many antarctic species share a close taxo- 
Table 1. Feeding modes and foods of antarctic and subantarctic echinoderms

\begin{tabular}{|c|c|c|c|}
\hline Species & Feeding mode/habit & Foods & Source \\
\hline \multicolumn{4}{|c|}{ Antarctic echinoderms } \\
\hline \multicolumn{4}{|l|}{ Asteroids } \\
\hline \multicolumn{4}{|l|}{ Astropectinidae } \\
\hline Bathybiaster loripes & $\begin{array}{l}\text { Ciliary mucoid?, } \\
\text { detritivore }\end{array}$ & Mud (organic detritus) & Dearborn (1977) \\
\hline \multirow{2}{*}{$\begin{array}{l}\text { Macroptychaster } \\
\text { accrescens }\end{array}$} & \multirow[t]{2}{*}{ Active predator } & Gastropods, bivalves, brittle stars & Dearborn (1977) \\
\hline & & $\begin{array}{l}\text { Sea star (Odontaster validus), sea } \\
\text { urchin (Sterechinus neumayeri) }\end{array}$ & Dayton et al. $(1970,1974)$ \\
\hline \multirow[t]{2}{*}{ Psilaster charcoti } & \multirow{2}{*}{$\begin{array}{l}\text { Ciliary mucoid?, } \\
\text { detritivore?, } \\
\text { active predator, } \\
\text { coprophagous, } \\
\text { necrophagous }\end{array}$} & $\begin{array}{l}\text { Mud (organic detritus), fecal } \\
\text { material, dead matter, fish, } \\
\text { polychaetes, ascidians }\end{array}$ & Dearborn (1977) \\
\hline & & Meat bait & Arnaud (1965) \\
\hline \multicolumn{4}{|l|}{ Benthopectinidae } \\
\hline Luidiaster gerbachei & Active predator & Ophiuroids, mud & Dearborn (1977) \\
\hline \multicolumn{4}{|l|}{ Odontasteridae } \\
\hline $\begin{array}{l}\text { Acodontaster } \\
\text { conspicuus }\end{array}$ & Spongivore & $\begin{array}{l}\text { Sponges (Tetilla leptoderma, Rosella } \\
\text { nuda, Scolymastia jubini, Rosella } \\
\text { racovitzae, Haliclona dancoi) }\end{array}$ & Dayton et al. $(1970,1974)$ \\
\hline \multirow[t]{2}{*}{$\begin{array}{l}\text { Acodontaster } \\
\text { hodgsoni }\end{array}$} & \multirow[t]{2}{*}{ Spongivore } & $\begin{array}{l}\text { Sponges (Haliclona dancoi, Calyx } \\
\text { arcuarius, Rosella racovitzae), feces }\end{array}$ & Dayton et al. $(1970,1974)$ \\
\hline & & Meat bait & Pearse \& Giese (1966) \\
\hline \multirow[t]{2}{*}{$\begin{array}{l}\text { Odontaster } \\
\text { meridionalis }\end{array}$} & \multirow{2}{*}{$\begin{array}{l}\text { Ciliary mucoid?, } \\
\text { spongivore, omnivore, } \\
\text { active predator, } \\
\text { coprophagous, } \\
\text { necrophagous }\end{array}$} & $\begin{array}{l}\text { Sponges (Homaxinella balfourensis, } \\
\text { Polymastia invaginata, Rosella } \\
\text { racovitzae), feces }\end{array}$ & $\begin{array}{l}\text { Dayton (1989), Dayton et } \\
\text { al. }(1970,1974)\end{array}$ \\
\hline & & Meat bait & Doderlein (1927) \\
\hline \multirow[t]{6}{*}{ Odontaster validus } & \multirow{6}{*}{$\begin{array}{l}\text { Ciliary mucoid?, } \\
\text { omnivore, spongivore, } \\
\text { filter feeder, scavenger, } \\
\text { herbivore, active } \\
\text { predator, coprophagous, } \\
\text { necrophagous }\end{array}$} & $\begin{array}{l}\text { Sponges, gastropods, nauplii, } \\
\text { ostracods, shrimp, sea urchin } \\
\text { (Sterechinus neumayeri), } \\
\text { diatoms, seal feces }\end{array}$ & Pearse $(1965,1969)$ \\
\hline & & $\begin{array}{l}\text { Sponges (Tetilla leptoderma, } \\
\text { Rosella racovitzae), bivalves } \\
\text { (Limatula hodgsoni, Laternula } \\
\text { elliptica), hydroid (Halecium } \\
\text { arboreum), ectoprocts, sea star } \\
\text { (Acodontaster conspicuus) }\end{array}$ & Dayton et al. $(1970,1974)$ \\
\hline & & Isopod (Glyptonotus antarcticus) & Peckham (1964) \\
\hline & & $\begin{array}{l}\text { Detritus, red algae, amphipods, } \\
\text { sponges }\end{array}$ & Dearborn (1977) \\
\hline & & Meat bait & $\begin{array}{l}\text { Arnaud (1965, 1974), } \\
\text { Pearse \& Giese (1966), } \\
\text { Clark (1963), Hoshiai } \\
\text { (1968), Numanami et } \\
\text { al. (1984) }\end{array}$ \\
\hline & & Bivalve (Laternula elliptica) & Zamorano et al. (1986) \\
\hline \multicolumn{4}{|l|}{ Solasteridae } \\
\hline \multirow{3}{*}{$\begin{array}{l}\text { Cuenotaster } \\
\text { involutus }\end{array}$} & \multirow{3}{*}{$\begin{array}{l}\text { Active predator, } \\
\text { necrophagous }\end{array}$} & Penguin meat & Arnaud $(1965,1970)$ \\
\hline & & Bivalves, polychaetes & Dearborn (1977) \\
\hline & & Meat bait & Arnaud (1974) \\
\hline \multirow{3}{*}{$\begin{array}{l}\text { Ganeriidae } \\
\text { Perknaster fuscus }\end{array}$} & \multirow{3}{*}{$\begin{array}{l}\text { Spongivore, ciliary } \\
\text { mucoid?, necro- } \\
\text { phagous }\end{array}$} & & \\
\hline & & Sponge (Mycale acerata) & Dayton et al. $(1970,1974)$ \\
\hline & & Fish & $\begin{array}{l}\text { Dearborn (1977), Pearse \& } \\
\text { Giese (1966) }\end{array}$ \\
\hline Perknaster densus & Necrophagous & Meat bait & Numanami et al. (1984) \\
\hline
\end{tabular}


Table 1 (continued)

\begin{tabular}{|c|c|c|c|}
\hline Species & Feeding mode/habit & Foods & Source \\
\hline \multicolumn{4}{|l|}{ Poraniidae } \\
\hline \multirow[t]{3}{*}{$\begin{array}{l}\text { Porania antarctica } \\
\text { glabra }\end{array}$} & \multirow{3}{*}{$\begin{array}{l}\text { Ciliary mucous, active } \\
\text { predator, omnivore, } \\
\text { necrophagous }\end{array}$} & $\begin{array}{l}\text { Detritus, diatoms, sponges, } \\
\text { ectoprocts }\end{array}$ & $\begin{array}{l}\text { Dearborn }(1965,1977) \\
\text { Clark }(1963)\end{array}$ \\
\hline & & $\begin{array}{l}\text { Sea urchin (Sterechinus neumayeri), } \\
\text { fish bait }\end{array}$ & Dearborn (1977) \\
\hline & & Meat bait & Numanami et al. (1984) \\
\hline \multicolumn{4}{|l|}{ Asteriidae } \\
\hline \multirow[t]{4}{*}{ Diplasterias brucei } & \multirow{4}{*}{$\begin{array}{l}\text { Active predator, } \\
\text { necrophagous, } \\
\text { ciliary mucoid? } \\
\text { coprophagous }\end{array}$} & Bivalve (Limatula hodgsoni) & Dearborn $(1965,1967)$ \\
\hline & & Gastropod (Trophon longstaffi) & Dayton et al. $(1970,1974)$ \\
\hline & & Feces & Arnaud $(1965,1970)$ \\
\hline & & Meat bait & $\begin{array}{l}\text { Arnaud (1974), Pearse \& } \\
\text { Giese (1966), Numanami } \\
\text { et al. (1984) }\end{array}$ \\
\hline Granaster nutrix & $\begin{array}{l}\text { Herbivore, active } \\
\text { predator }\end{array}$ & $\begin{array}{l}\text { Red algae, gastropods, } \\
\text { ectoprocts }\end{array}$ & Dearborn $(1977)$ \\
\hline Labidiaster annulatus & $\begin{array}{l}\text { Active predator, } \\
\text { spongivore?, copro- } \\
\text { phagous, necrophagous }\end{array}$ & $\begin{array}{l}\text { Fish, euphausids, ophiuroids, } \\
\text { gastropods, amphipods, bivalves, } \\
\text { crinoids, polychaetes, asteroids, } \\
\text { isopods, echinoids, feces }\end{array}$ & $\begin{array}{l}\text { Dearborn (1977), Dearborn } \\
\text { et al. }(1972), \text { Dearborn \& } \\
\text { Fell }(1974)\end{array}$ \\
\hline \multirow[t]{2}{*}{ Lyasterias perrieri } & \multirow{2}{*}{$\begin{array}{l}\text { Necrophagous, active } \\
\text { predator, passive } \\
\text { ciliary, mucoid feeder? }\end{array}$} & Bivalves, dead animals & Dearborn (1977) \\
\hline & & Ostracods, brittle stars & Arnaud $(1965,1970)$ \\
\hline $\begin{array}{l}\text { Neosmilaster } \\
\text { georgianus }\end{array}$ & $\begin{array}{l}\text { Active predator } \\
\text { necrophagous }\end{array}$ & $\begin{array}{l}\text { Meat bait, gastropods, } \\
\text { polychaetes, bivalves, limpets }\end{array}$ & Dearborn (1977) \\
\hline Notasterias armata & $\begin{array}{l}\text { Active predator, } \\
\text { scavenger }\end{array}$ & Bivalve (Limutula hodgsoni) & Dearborn (1977) \\
\hline Saliasterias brachiata & Necrophagous & Meat bait & Arnaud $(1965,1970)$ \\
\hline \multicolumn{4}{|l|}{ Brisingidae } \\
\hline Odinella nutrix & Active predator & Crustaceans (mysids) & Dearborn (1977) \\
\hline \multicolumn{4}{|l|}{ Ophiuroids } \\
\hline $\begin{array}{l}\text { Gorgonocephalidae } \\
\text { Astrochlamys bruneus }\end{array}$ & Active predator & Coelenterates, polyps, ectoprocts & Dearborn $(1977)$ \\
\hline $\begin{array}{l}\text { Astrohamma } \\
\text { tuberculatum }\end{array}$ & Active predator & Hydrococoral polyps & Fell (1961), Dearborn (1977) \\
\hline \multirow[t]{3}{*}{ Astrotoma agassizii } & \multirow[t]{3}{*}{$\begin{array}{l}\text { Active predator? } \\
\text { zooplanktivore }\end{array}$} & $\begin{array}{l}\text { Crustaceans, copepods } \\
\text { Hyperiid amphipods, plankton? }\end{array}$ & $\begin{array}{l}\text { Mortensen (1936) } \\
\text { Fell (1961) }\end{array}$ \\
\hline & & Copepods & $\begin{array}{l}\text { Dearborn (1977), Dearborn } \\
\text { et al. (1986), Ferrari \& } \\
\text { Dearborn (1989) }\end{array}$ \\
\hline & & Meat bait & Fell $(1961)$ \\
\hline $\begin{array}{l}\text { Gorgonocephalus } \\
\text { chiliensis }\end{array}$ & Zooplanktivore & Copepods & Dearborn (1977) \\
\hline \multicolumn{4}{|l|}{ Ophiuridae } \\
\hline \multirow[t]{3}{*}{ Ophionotus victoriae } & \multirow{3}{*}{$\begin{array}{l}\text { Active predator, } \\
\text { cannibalistic, } \\
\text { omnivore, } \\
\text { planktivore? }\end{array}$} & Euphausids, polychaetes & Dearborn (1977) \\
\hline & & $\begin{array}{l}\text { Sponges, copepods, feces, forams, } \\
\text { cnidarians, nematodes, annelids, } \\
\text { mysids, isopods, bryozoans, } \\
\text { echinoids, crinoids, ascidians, } \\
\text { asteroids, bivalves, amphipods. } \\
\text { diatoms, ophiuroids, hydroids, } \\
\text { detritus }\end{array}$ & Fratt \& Dearborn (1984) \\
\hline & & Meat bait & $\begin{array}{l}\text { Arnaud (1974), Numanami } \\
\text { et al. (1984) }\end{array}$ \\
\hline
\end{tabular}


Table 1 (continued)

\begin{tabular}{|c|c|c|c|}
\hline Species & Feeding mode/habit & Foods & Source \\
\hline \multirow[t]{4}{*}{ Ophiurolepis gelida } & \multirow{4}{*}{$\begin{array}{l}\text { Selective detritus } \\
\text { feeder, active } \\
\text { predator }\end{array}$} & Detritus & Fell (1961) \\
\hline & & $\begin{array}{l}\text { Crustaceans, diatoms, forams, } \\
\text { polychaetes, gastropods, feces }\end{array}$ & Dearborn (1977) \\
\hline & & Fish & Dearborn $(1965,1967)$ \\
\hline & & Meat bait & Fell $(1961)$ \\
\hline Ophiurolepis martensi & Active predator & Meat bait & Fell (1961) \\
\hline Ophiosteira echinulata & Active predator? & Meat bait & Fell (1961) \\
\hline \multicolumn{4}{|l|}{ Ophioleucidae } \\
\hline Ophioperla koehleri & $\begin{array}{l}\text { Active predator, } \\
\text { zooplanktivore }\end{array}$ & $\begin{array}{l}\text { Euphausids, polychaetes, ophiuroids, } \\
\text { sponges, crinoids, forams, } \\
\text { copepods, echinoids }\end{array}$ & Dearborn (1977) \\
\hline \multicolumn{4}{|l|}{ Ophiacanthidae } \\
\hline \multirow{2}{*}{ Ophiacantha antarctica } & \multirow{2}{*}{$\begin{array}{l}\text { Active forager, } \\
\text { planktivore }\end{array}$} & Diatoms, forams, copepods & Dearborn (1977) \\
\hline & & Meat bait & Fell (1961) \\
\hline Ophiacantha pentactis & $\begin{array}{l}\text { Planktivore? } \\
\text { suspension feeding? }\end{array}$ & Copepods & Fell (1961), Dearborn (1977) \\
\hline \multirow[t]{2}{*}{ Ophiacantha vivipara } & \multirow[t]{2}{*}{ Zooplanktivore } & Copepods & Dearborn (1977) \\
\hline & & Meat bait & Fell (1961) \\
\hline Ophiosparte gigas & $\begin{array}{l}\text { Active predator, } \\
\text { necrophagous }\end{array}$ & $\begin{array}{l}\text { Meat bait } \\
\text { Ophiuroids, polychaetes }\end{array}$ & $\begin{array}{l}\text { Arnaud (1974) } \\
\text { Dearborn }(1977)\end{array}$ \\
\hline \multicolumn{4}{|l|}{ Echinoids } \\
\hline \multicolumn{4}{|l|}{ Echinidae } \\
\hline \multirow[t]{4}{*}{ Sterechinus neumayeri } & \multirow{4}{*}{$\begin{array}{l}\text { Omnivore, herbivorous, } \\
\text { grazer, coprophagous }\end{array}$} & Diatoms, seal feces, red algae & Pearse \& Giese (1966) \\
\hline & & Meat bait & $\begin{array}{l}\text { Arnaud (1974), Pearse \& } \\
\text { Giese (1966), Numanami } \\
\text { et al (1984) }\end{array}$ \\
\hline & & Scallops & Stockton (1984) \\
\hline & & $\begin{array}{l}\text { Algae, bryozoans, hydrozoans, } \\
\text { Spirorbis sp., diatoms, amphipods, } \\
\text { forams }\end{array}$ & Brand $(1980)$ \\
\hline Sterechinus antarctica & Omnivore? & Bryozoans & T Brey (unpubi.) \\
\hline \multicolumn{4}{|l|}{ Schizasteridae } \\
\hline Abatus nimrodi & Deposit feeder & Organically coated sediments & $\begin{array}{l}\text { Pearse \& McClintock } \\
\text { (unpubl.) }\end{array}$ \\
\hline Abatus shackletoni & Deposit feeder & Organically coated sediments & $\begin{array}{l}\text { Pearse \& McClintock } \\
\text { (unpubl.) }\end{array}$ \\
\hline \multicolumn{4}{|l|}{ Cidaridae } \\
\hline $\begin{array}{l}\text { Austrocidaris } \\
\text { canaliculata }\end{array}$ & $\begin{array}{l}\text { Carnivore, } \\
\text { scavenger }\end{array}$ & Forams, gastropods & Fell (1976) \\
\hline Aporocidaris milleri & $\begin{array}{l}\text { Carnivore, } \\
\text { scavenger }\end{array}$ & $\begin{array}{l}\text { Polychaetes, forams, hydroids, } \\
\text { gastropods, amphipods }\end{array}$ & Fell (1976) \\
\hline Ctenocidaris perrieri & $\begin{array}{l}\text { Carnivore, } \\
\text { scavenger }\end{array}$ & $\begin{array}{l}\text { Polychaetes, bryozoans, tunicates, } \\
\text { sponges, forams }\end{array}$ & Fell (1976) \\
\hline Ctenocidaris gilberti & $\begin{array}{l}\text { Carnivore, } \\
\text { scavenger }\end{array}$ & Sponges, forams, bryozoans & Fell (1976) \\
\hline \multicolumn{4}{|l|}{ Holothuroids } \\
\hline Psolus charcoti & $\begin{array}{l}\text { Necrophagous, } \\
\text { suspension feeder }\end{array}$ & Meat bait & Arnaud (1974) \\
\hline Heterocucumis vaneyi & $\begin{array}{l}\text { Necrophagous, } \\
\text { suspension feeder }\end{array}$ & Meat bait & Arnaud (1974) \\
\hline Heterocucumis denticulata & $\begin{array}{l}\text { Necrophagous, } \\
\text { suspension feeder }\end{array}$ & Meat bait & Arnaud (1974) \\
\hline
\end{tabular}


Table 1 (continued)

\begin{tabular}{|c|c|c|c|}
\hline Species & Feeding mode/habit & Foods & Source \\
\hline Hypsilocucumis turricata & $\begin{array}{l}\text { Necrophagous, } \\
\text { suspension feeder }\end{array}$ & Meat bait & Arnaud (1974) \\
\hline Heterocucumis coatsi & $\begin{array}{l}\text { Necrophagous, } \\
\text { suspension feeder }\end{array}$ & Meat bait & Arnaud (1974) \\
\hline \multicolumn{4}{|l|}{ Crinoid } \\
\hline \multirow[t]{2}{*}{$\begin{array}{l}\text { Promachocrinus } \\
\text { kerguelensis }\end{array}$} & Filter feeder & Plankton & $\begin{array}{l}\text { Pearse \& McClintock } \\
\text { (unpubl.) }\end{array}$ \\
\hline & \multicolumn{2}{|c|}{ Subantarctic echinoderms } & \\
\hline \multicolumn{4}{|l|}{ Asteroids } \\
\hline \multirow[t]{2}{*}{ Anasterias perrieri } & Active predator & Meat bait & Arnaud (1974) \\
\hline & Necrophagous & $\begin{array}{l}\text { Crab (Halicarcinus planatus), } \\
\text { limpet (Nacella edgari) }\end{array}$ & McClintock (1985) \\
\hline \multirow[t]{2}{*}{ Anasterias rupicola } & Active predator & Limpet (Nacella delesserti) & Blankley \& Branch (1984) \\
\hline & & $\begin{array}{l}\text { Polychaetes, bivalves, chitons, } \\
\text { isopods, amphipods }\end{array}$ & Blankley (1984) \\
\hline \multicolumn{4}{|l|}{ Holothuroids } \\
\hline Ekmocucumis spatha & $\begin{array}{l}\text { Planktivore, } \\
\text { active predator }\end{array}$ & $\begin{array}{l}\text { Diatom (Pororsira glacialis), } \\
\text { algae, sponge, copepods, } \\
\text { amphipods, ostracods, bryozoans, } \\
\text { forams }\end{array}$ & Brand (1980) \\
\hline Heterocucumis antarcticus & $\begin{array}{l}\text { Planktivore, } \\
\text { active predator }\end{array}$ & $\begin{array}{l}\text { Diatom (Pororsira glacialis), } \\
\text { algae, sponge, copepods, } \\
\text { amphipods, ostracods, bryozoans, } \\
\text { forams }\end{array}$ & Brand (1980) \\
\hline Cucumaria attenuata & $\begin{array}{l}\text { Planktivore, } \\
\text { active predator }\end{array}$ & $\begin{array}{l}\text { Diatom (Pororsira glacialis), } \\
\text { algae, sponge, copepods, } \\
\text { amphipods, ostracods, bryozoans, } \\
\text { forams }\end{array}$ & Brand (1980) \\
\hline Cucumaria georgiana & $\begin{array}{l}\text { Planktivore, } \\
\text { active predator }\end{array}$ & $\begin{array}{l}\text { Diatom (Pororsira glacialis), } \\
\text { algae, sponge, copepods, } \\
\text { amphipods, ostracods, bryozoans, } \\
\text { forams }\end{array}$ & Brand (1980) \\
\hline
\end{tabular}

nomic affinity with deep-sea species (e.g. Madsen 1961), many known to be scavengers. He divides antarctic echinoderms into both seasonal and yearround necrophages, citing the asteroid Odontaster validus and the echinoid Sterechinus neumayeri as examples of seasonal necrophages, and the asteroid Diplasterias brucei as a non-seasonal necrophagous feeder. It is important to note that gut contents analyzed from many antarctic echinoderms caught in traps with meat bait contain prey items indicative of foraging on living prey. Therefore, the relative importance of necrophagy in the diets of antarctic echinoderms must be viewed as a component of a generalistic feeding strategy (Warner 1982).

Detritivores are also relatively common among antarctic and subantarctic echinoderms (Table 1). Moreover, this feeding behavior is probably underestimated due to the difficulty of identifying detritus from guts, or in asteroids, the difficulty of documenting the presence of detrital matter in contact with the extruded cardiac stomach. Organic detritus has been identified as a primary food source in the astropectinid asteroid Bathybiaster loripes, a species which mostly ingests mud, and the omnivorous odontasterid asteroid Odontaster validus (Dayton et al. 1974, Dearborn 1977).

Detrital feeding in $O$. validus is thought to serve as a 'larval filter' regulating the abundances of 2 of the most important sponge predators in McMurdo Sound, the asteroid Acodontaster conspicuus and the dorid nudibranch Austrodoris mcmurdensis (Dayton et al. 1974). Detrital material has also been observed as one of many food items in another common astropectinid. Psilaster charcoti (Dearborn 1977). A total of $7 \%$ of the diet of the subantarctic asteroid Anasterias perrieri was detrital (McClintock 1985). Among antarctic ophiuroids, Ophiurolepis gelida is considered by Fell 
(1961) a selective detritus feeder, while detritus and sediments have been found in the guts of the omnivorous Ophionotus hexactis and $O$. victoriae (Dearborn 1977, Morrison 1979, Fratt \& Dearborn 1984). Two antarctic infaunal holothuroids, Paradota weddellensis and Molpadia musculus, are detritivores (Gutt 1991). No antarctic echinoids have been observed to feed on detrital material. Nonetheless, the irregular echinoids Abatus shackletoni and $A$. nimrodi feed on sediments that are laden with fine detrital material (J. S. Pearse \& J. B. McClintock pers. obs.).

Plankton or nekton feeding has been observed in several classes of antarctic echinoderms, particularly among ophiuroids (Table 1). The asteroid Labidiaster annulatus consumes euphausids (Fisher 1940) using its pedicellariae and podia (Dearborn et al. 1982). In some habitats, as much as $80 \%$ of the volume of prey captured by $L$. annulatus consists of krill (Dearborn \& Edwards 1984). Remarkably, this asteroid also has the ability to capture and ingest fish (Dearborn 1977). Observing films taken in situ, Dearborn (1977) noted that $L$. annulatus waves its flexible arms through the water until contacting a fish, at which time the arm-tip is wrapped quickly around the prey. Planktivory has been observed in the common ophiuroid Astrotoma agassizii (Mortensen 1936, Fell 1961, Dearborn 1977. Dearborn et al. 1983). Planktonic copepods make up a large percentage of the stomach contents. Dearborn (1977) observed adults photographed on the benthos of the Ross Sea had a feeding posture characterized by extensive twisting and coiling of the long arms, and that prey were apparently caught at the tip of the arm, the arm rolled up, and prey transferred to the mouth. Copepods have also been found in the stomach contents of the ophiuroids Ophionotus hexactis and $O$. victoriae. Whether these species actively capture plankton from the water column is unknown. The ophiuroids Ophiacantha antarctica, $O$. pectactis and $O$. vivipara have long arm-spines which appear to be an adaptation for planktivory. Warner (1982) speculated that in addition to planktonic organisms becoming entangled in these long spines, both mucus and podia may be involved in prey capture. Copepods have been found in the guts of all 3 species (Fell 1961, Dearborn 1977). The subantarctic echinoid Dermechinus horridus displays a very unique suspension feeding strategy (Fell 1976). Individuals cluster on sides of large boulders oriented towards the current, spreading their spines to catch suspended detritus and plankton with their fur-like secondary spines. Four species of subantarctic holothuroids (see Table 1) are known to ingest phytoplankton during the austral spring and summer, primarily the diatom Pororsira glacialis (Brand 1980). Although antarctic crinoids are presumably plankton feeders, no information is available on their feeding habits. The extremely common Promachocrinus kerguelensis is often seen perched on sponges or sediments with its arm held in a 'filtering posture' (photograph in Dearborn 1977, McClintock \& Pearse 1987).

\section{Antarctic echinoderms as spongivores}

When compared to asteroids from temperate and tropical latitudes, spongivory among antarctic asteroids appears to be unusually common (Dayton et al. 1974, Dayton 1979, 1989, Sloan 1980). Dayton et al. (1974) have extensively studied the spongivorous feeding habits of 5 common species of asteroids in McMurdo Sound, Antarctica. They found that 11 species of siliceous sponges comprised a significant proportion of the diets of Odontaster validus, O. meridionalis, Acodontaster conspicuus and A. hodgsoni. Moreover, the asteroid Perknaster fuscus was a specialist feeder on the fast growing sponge Mycale acerata, while having a more catholic diet as a juvenile (Dayton et al. 1974). Predation by P. fuscus on M. acerata had very significant ecological implications, as this sponge dominated epibenthic space when freed from predation pressure. Sponge prey which were particularly common in other antarctic asteroid diets included the root sponge Rosella racovitzae, the basketball sponge Tetilla leptoderma and rosellid volcano sponges. There is evidence that some antarctic sponges are chemically defended from sea star predation (McClintock 1987, McClintock et al. 1990, 1994, Baker et al. in press).

The basis for the preponderance of spongivory among antarctic asteroids is unknown. Certainly there are alternative prey available including benthic molluscs, prey commonly eaten by temperate and tropical asteroids (Sloan 1980). However, bivalve and gastropod prey are comparatively rare and it is likely that while antarctic sponges are low in nutrient and energy content (McClintock 1987), their extreme abundance offers an abundant, stable, low-energy resource in a nutrient-limited system (Lawrence \& McClintock in press). One hypothesis is that feeding specialization would be favored when low-energy resources are predictable both temporally and spatially (Fox \& Morrow 1981, Pyke 1984).

Spongivory appears to be less common in antarctic ophiuroids. Pieces of sponges have been recovered from the stomachs of Ophionotus victoriae (Fratt \& Dearborn 1984) and Ophioperla koehleri, both of which feed on a wide variety of prey (Dearborn 1977). The subantarctic Ophionotus hexactis have been collected with guts containing sponge spicules, particularly in deep water $(200 \mathrm{~m})$ (Morrison 1979). Brand 
(1980) notes that 4 species of subantarctic holothuroids ingest small amounts of sponge material near Palmer Station on the Antarctic Peninsula. Sponges were only found in the gut during the early austral fall when phytoplankton was not available. Similar to a number of temperate and tropical cidaroid echinoids, Ctenodiscus perrieri and $C$. gilberti include sponges in their varied diets (Fell 1976, DeRidder \& Lawrence 1982).

\section{Antarctic echinoderms as active predators of benthic macrofauna (excluding sponges)}

With several notable exceptions (e.g. specialist spongivores, detritivores, mucoid ciliary feeders), antarctic asteroids include a wide variety of macrofauna in their diets (Table 1). Most active foraging species are generalists in their feeding habits. Common prey include bivalves, gastropods and ophiuroids, while echinoids, polychaetes, ostracods, mysids, amphipods, isopods, ectoprocts and ascidians occur less frequently. One of the most active predatory asteroids is Labidiaster annulatus, which Dearborn (1977) likens to the voracious Pacific coast asteroid Pycnopodia helianthoides. However, Dearborn et al. (1991) note that these 2 sea stars differ in that $L$. annulatus obtains a high percentage of its prey from the water column, while $P$. helianthoides primarily feeds on bivalves and echinoids. L. annulatus feeds on 50 or more prey types (Dearborn \& Edwards 1984, Dearborn et al. 1991), including fish, euphausids, ophiuroids, gastropods, bivalves, crinoids, polychaetes, asteroids, isopods, amphipods and echinoids. Common prey include amphipods and euphausiids caught with the pedicellariae and annuli along the arms (Dearborn et al. 1991). Exceptions to the generalist feeding behavior of most antarctic asteroids include the shallow water Granaster nutrix which feeds almost exclusively on small gastropods (Dearborn \& Edwards 1984), and Diplasterias brucei which Dayton et al. (1974) observed to feed almost entirely on the bivalve Limatula hodgsoni in McMurdo Sound. At least 2 antarctic nudibranchs and a lamellarian gastropod appear to be chemically defended from sea star predation (Davies-Coleman \& Faulkner 1991, McClintock et al. 1992, in press). Cannibalism has not been reported in antarctic asteroids. Nonetheless, intergeneric predation events occur. Dayton et al. (1974) documented a massive feeding aggregation of Odontaster validus, with their stomachs extruded and digesting the body wall of the much larger sea star Acodontaster conspicuus. $O$. validus feeds on wounded individuals of Perknaster fuscus antarcticus in the laboratory (McClintock pers obs.). Sea star remains have been found in the gut of Labidiaster annulatus (Dearborn 1977), and the large Macropty- chaster accrescens occasionally ingests the much smaller O. validus (Dayton et al. 1970, 1974).

Among subantarctic asteroids, McClintock (1985) documented the field diet of the common subtidal sea star Anasterias perrieri in a kelp forest in the Bay of Morbihan, Kerguelen. Of 16 individuals examined while feeding, 15 had captured mobile prey including the crab Halicarcinus planatus and the limpet Nacella edgari. Blankley \& Branch (1984) investigated the foraging behavior of the subantarctic littoral asteroid Anasterias rupicola on Marion Island. Interestingly, they discovered what appeared to be 'cooperative' prey capture of the limpet $N$. delesserti, a behavior which according to the investigators facilitated the capture and ingestion of larger prey. Other prey of A. rupicola included polychaetes, bivalves, chitons, isopods and amphipods, all of which occurred much less frequently than limpets (Blankley 1984). While more information is needed, subantarcic asteroids feed on more active, higher-energy prey than their higher-latitude antarctic counterparts.

Nine of 15 species of antarctic ophiuroids examined for feeding habits clearly display active foraging strategies (Table 1). Non-echinoderm prey recovered from stomach contents include cnidarians, ectoprocts, nematodes, mysids, annelids, bryozoans, ascidians, polychaetes, foraminiferans, crustaceans, bivalves and gastropods (Table 1). Among echinoderm prey, echinoids and crinoids have been recovered from the guts of Ophioperla koehleri, while ophiuroids have been collected from the stomachs of Ophionotus hexactis, $O$. victoriae, $O$, koehleri and Ophiosparte gigas. In addition to feeding more commonly on other species of ophiuroids, $O$. victoriae is also cannibalistic on juveniles (Dearborn 1977). Moreover, Fratt \& Dearborn (1984) documented the remains of crinoids and asteroids in the gut of $O$. victoriae. Antarctic echinoids are also active predators on macroinvertebrates (Table 1). The echinoid Sterechinus neumayeri ingests scallops, bryozoans, hydrozoans, amphipods and foraminiferans (Brand 1980, Stockton 1984). Less is known about the diet of its congenor $S$. antarcticus which feeds on bryozoans (T Brey unpubl. obs.). Stomach contents of antarctic cidarid sea urchins are also indicative of generalist feeding habits and these sea urchins have been observed to include gastropods, polychaetes, foraminiferans, hydroids, amphipods, ascidians and bryozoans in their diets (Fell 1976).

Four species of subantarctic holothuroids (see Table 1) are feeding generalists on benthic fauna during the early austral fall when phytoplankton, their preferred food, is unavailable (Brand 1980). Fauna included in their diets consists of macroalgae, sponges, copepods, amphipods, ostracods, bryozoans and foraminiferans. 


\section{Coprophagy in antarctic echinoderms}

The ingestion of fecal material is not unique to antarctic echinoderms, but to asteroids and echinoids in general. Pearse (1965) noted that antarctic echinoderms may opportunistically consume fecal material. In McMurdo Sound, Pearse observed coprophagy in the antarctic asteroid Odontaster validus as well as the echinoid Sterechinus neumayeri (Pearse \& Giese 1966), both of which consumed Weddell seal feces when available. Since Pearse's study, a number of investigators have documented coprophagy in additional antarctic asteroids (Psilaster charcoti, Acodontaster hodgsoni, O. meridionalis, Diplasterias brucei, Labidiaster annulatus) and ophiuroids (Ophionotus victoriae, Ophiurolepis gelida) (Table 1). The same arguments for the prevalence of necrophagy in antarctic echinoderms (see above) apply to the high incidence of coprophagy in antarctic echinoderms.

\section{Antarctic echinoderms as ciliary mucoid feeders}

A ciliary mode of feeding has been postulated for a number of antarctic asteroids (Table 1). Jangoux (1982) defined ciliary-feeding asteroids as individuals which collect particulate food from the substratum employing cilia on the oral body surface and/or everted cardiac stomach. The antarctic sea star Porania antarctica glabra has been suggested to use cilia covering its oral surface to generate water currents directed towards the oral opening (Clark 1963, Dearborn 1977). Other antarctic asteroids are thought to use the stomach as a ciliary-feeding organ using mucus to facilitate the capture of surface detrital material and microorganisms. Among those antarctic species thought to employ a ciliary-mucoid mode of feeding are Bathybiaster loripes, Psilaster charcoti, Odontaster meridionalis, $O$. validus, Perknaster fuscus, Diplasterias brucei and Lyasterias perrieri (Pearse 1965, Dearborn 1977). Ciliary-mucoid feeding has not been reported in antarctic ophiuroids, echinoids, holothuroids or crinoids.

\section{Antarctic echinoderms as algal grazers}

Pearse $(1965,1969)$ found that benthic diatoms comprised a significant portion of the diet of the common asteroid Odontaster validus in McMurdo Sound. Dearborn (1977) also reported that stomach contents of $O$. validus in McMurdo Sound contained diatoms as well as red algae. O. validus feeds on the red alga Iridaea cordatum at Cape Evans, McMurdo Sound (M. Slattery pers. comm.). McClintock et al. (1988) proposed that grazing of plant (primarily diatom) material may explain differences in biomass of populations of $O$. validus in several contrasting habitats within McMurdo Sound. Higher levels of chlorophyll in the pyloric caeca and richer red pigmentation of the body wall in shallow-water individuals indicate populations in these habitats exploit abundant primary production. Individuals in deeper water or at shallow water sites with snow covered permanent sea ice, where light penetration was reduced, have lower levels of chlorophyll in their pyloric caeca, lighter body coloration, and 4 to 9 times reduced population biomass. Smith et al. (1986) found large proportions of lipids indicative of the sea ice diatom Nitzschia cylindrus and the planktonic microalgae Phaeocystis pouchetii in the stomachs of $O$. validus. Other than that noted in $O$. validus, herbivory is rare among antarctic asteroids, although the small asteroid Granaster nutrix is apparently an herbivore on red algae as well as a predator of gastropods (Dearborn 1977). Diatoms have been found in the gut of the asteroid Porania antarctica gelida and the ophiuroid Ophiocantha antarctica, both of which appear to have broad diets which include mostly animal prey (Dearborn 1977). The subantarctic $O$. hexactis has been observed with diatoms as well as marine algae and terrestrial plant material in its gut (Morrison 1979).

Pearse \& Giese (1966) found that individuals of the common antarctic regular echinoid Sterechinus neumayeri at Cape Evans, McMurdo Sound, feed on an abundant diatom carpet which was present during the austral spring from February to April. Diatoms were the most conspicuous component of fecal pellets during this time period as well as fecal samples examined in November and December. Pearse \& Giese (1966) suggested that the foliose red alga Iridaea sp. might also provide some nourishment for $S$. neumayeri, and Fell (1976) found pellets of 'macroalgae' in the stomachs of this species on the Antarctic Peninsula in March. Nonetheless, both field and laboratory observations documented only limited herbivory in S. neumayeri on either of the 2 fleshy red algae (Iridaea cordata, Phyllophora antarctica) which occur in McMurdo Sound (Miller \& Pearse 1991, M. Slattery, P. Bryan \& J. B. McClintock pers. obs.). It is curious why these omnivorous sea urchins do not include these abundant algae in their diets in proportion to their availability. One of these red algae, $P$, antarctica, contains cytotoxic secondary metabolites which could serve as feeding deterrents (B. J. Baker \& J. B. McClintock unpubl.). Bioactive metabolites which can have feeding deterrent properties have been isolated from a number of temperate and tropical red algae (Faulkner 1993 and references within). On the Antarctic Peninsula, Brand (1980) noted that the majority of the diet of $S$. neumayeri was comprised of the brown alga Desmerestia sp. Although there are extensive kelp 
forests surrounding a number of subantarctic islands, there is a conspicuous absense of intense grazing by regular echinoids. Harrold \& Pearse (1987) point out that the relative absense of intensively grazed kelp forests in the Southern Hemisphere remains a puzzle.

\section{SUMMARY}

Antarctic echinoderms appear to expend little energy on feeding and therefore are considered to be primarily low-energy feeders (Lawrence \& McClintock in press). Most are opportunistic scavengers or necrophages (Arnaud 1970, Dearborn 1977, Sloan 1980, Lawrence \& McClintock in press), and a substantial number exploit detritus or feed on suspended material (Dearborn 1977). While most antarctic species are feeding generalists, dietary specialization does occur, but appears to be limited to low-energy, highly abundant foods, such as sponges. These feeding strategies support earlier predictions that antarctic echinoderms are trophically adapted to a physically stable, lowenergy environment. It is evident that antarctic echinoderms, although low-energy feeders, can still exert a significant impact on levels of production of other macroinvertebrate groups (Dayton et al. 1974). This is well exemplified by the feeding of many antarctic asteroids on sponges, some of which are known to be important determinants of community structure in antarctic benthos (Dayton et al. 1974). Moreover, antarctic echinoderms are likely to have an important impact on microbial productivity (Kellogg et al. 1982, Dayton 1990, White et al. 1993), as all echinoderm classes have representatives that feed on benthic and planktonic microorganisms. In summary, it is evident that echinoderms are likely to play a significant and complex role in trophic energy transfer in antarctic benthic systems.

Clearly much more quantitative information is needed on the feeding habits and nutrient and energy intake of antarctic, and particularly subantarctic, echinoderms. Of particular interest will be studies which address the contribution of dissolved organic material to the nutrient and energy requirements of antarctic echinoderms. Moreover, the enigma of how filter-feeding echinoderms, such as crinoids, survive extensive periods of time with no obvious source of planktonic food must be considered.

Acknowledgements. I thank Bill Baker, Patrick Bryan, John Heine, Marc Slattery and especially John Lawrence, John Pearse and John Dearborn for their valuable editorial comments and insights. The preparation of this review paper was greatly facilitated with support provided by 2 grants from the National Science Foundation's Division of Polar Programs awarded to J.B.MCC. (OPP-8815959, OPP-9118864). I also acknowledge financial support provided by the 1993 University of Alabama at Birmingham Ireland Academic Scholarship Award. This paper is dedicated to Mark McMillan, a student from the University of California at Santa Cruz, who, in his much too short life, contributed to the field of antarctic benthic ecology.

\section{LITERATURE CITED}

Arnaud, P. M. (1965). Echinoderms littoraux de Terre Adélie (holothuries exceptées) et pélécypodes commensaux d'échinides antarctiques. Exp. polaires françaises (Missions P. E. Victor) 258: 1-71

Arnaud, P. M. (1970). Frequency and ecological significance of necrophagy among the benthic species of Antarctic coastal waters. In: Holgate, M. W. (ed.) Antarctic ecology, Vol. 1. Academic Press, New York, p. 259-266

Arnaud, P. M. (1974). Contribution à la bionomie marine benthique des régions antarctiques et sub-antarctiques. Téthys 6: 467-653

Baker, B. J., Kopitzke, R. W., Hamann, M., McClintock, J. B. (in press). Chemical ecology of antarctic marine invertebrates in McMurdo Sound, Antarctica: chemical aspects. Antarct. J. U.S

Blankley, W. O. (1984). Ecology of the starfish Anasterias rupicola at Marion Island (Southern Ocean). Mar. Ecol. Prog. Ser. 18: 131-137

Blankley, W. O., Branch, G. M. (1984). Co-operative prey capture and unusual brooding habits of Anasterias rupicola (Verrill) (Asteroidea) at sub-antarctic Marion Island. Mar. Ecol. Prog. Ser. 20: 171-176

Brand, T. E. (1980). Trophic interactions and community ecology of the shallow-water marine benthos along the Antarctic Peninsula. Ph.D. thesis, Univ. of California, Davis

Brey, T., Clarke, A. (1993). Population dynamics of marine benthic invertebrates in Antarctic and Sub-Antarctic environments: are these unique adaptations? Antarctic Sci 5: $253-266$

Clark, H. E. S. (1963). The fauna of the Ross Sea, Part 3, Asteroidea. Mem. N.Z. Oceanogr. Inst. 21: 1-184

Clarke, A. (1980). A reappraisal of the concept of metabolic cold adaptation in polar marine invertebrates. Biol. J. Linn. Soc. 14: $77-92$

Clarke, A. (1983). Life in cold water: the physiological ecology of polar marine ectotherms. Oceanogr. mar. Biol. A. Rev. 21: $341-453$

Davies-Coleman, M. T., Faulkner, D. J. (1991). New diterpenoic acid glycerides from the antarctic nudibranch Austrodoris mcmurdensis. Terahedron 47: 9743-9750

Dayton, P. K. (1979). Observations on growth, dispersal and population dynamics of some sponges in McMurdo Sound, Antarctica. In: Levi, C., Bourny-Esnault, N. (eds.) Proc. Colloquium Sponge Biology, Paris 1978. Centre National de la Recherche Scientifique, Paris, p. 271-278

Dayton, P. K. (1989). Interdecadel variation in an antarctic sponge and its predators from oceanographic climate shifts. Science 245: 1484-1486

Dayton, P. K. (1990). Polar benthos. In: Smith, W. O. (ed.) Polar oceanography, Part B, Chemistry, biology and geology. Academic Press, New York, p. 631-685

Dayton, P. K., Robilliard, G. A., Paine, R. T (1969). Anchor ice formation in McMurdo Sound, and its biological effects. Science 163: 273-274

Dayton, P. K. Robilliard, G. A., Paine, R. T (1970). Benthic faunal zonation as a result of anchor ice at McMurdo 
Sound, Antarctica. In: Holgate, M. W. (ed.) Antarctic ecology, Vol. 1. Academic Press, New York, p. 244.258

Dayton, P. K., Robilliard, G. A., Paine, R. T., Dayton, L. B (1974). Biological accommodation in the benthic community at McMurdo Sound, Antarctica. Ecol. Monogr. 44 $105-128$

Dearborn, J. H. (1965). Ecological and faunistic investigations of the marine benthos at McMurdo Sound, Antarctica Ph.D thesis, Stanford University

Dearborn, J. H. (1967). Stanford University invertebrate studies in the Ross Sea, 1958-1961: general account and station list, The fauna of the Ross Sea, Part 5, General accounts, station lists, and benthic ecology. N. Z. Dept. Sci. Ind. Res. Bull, 176: 31-47

Dearborn, J. H. (1977). Food and feeding characteristics of antarctic asteroids and ophiuroids. In: Llano, G. A. (ed.) Adaptations within antarctic ecosystems. Gulf Publ. Co., Houston, p. 293-326

Dearborn, J. H., Allen, K. W., Hureau, J. C., Arnaud, P. M. (1972). Ecological and taxonomic studies of echinoderms, molluscs and fishes from the Antarctic Peninsula. Antarct. J. U.S. 7 : $82-84$

Dearborn, J. H., Edwards, K. C. (1984). Analysis of data on the feeding biology of antarctic sea stars and brittle stars. Antarct. J. U.S. 19: 138-139

Dearborn, J. H., Edwards, K. C., Fratt, D. B. (1991). Diet, feeding behavior, and surface morphology of the multi-armed antarctic sea star Labidiaster annulatus (Echinodermata: Asteroidea). Mar. Ecol. Prog. Ser. 77: 65-84

Dearborn, J. H., Edwards, K. C., Fratt, D. B., Zamer, W. E. (1983). Echinoderm studjes along the Antarctic Peninsula. Antarct. J. U.S. 1: 193-194

Dearborn, J. H., Fell, F. J. (1974). Ecology of echinoderms from the Antarctic Peninsula. Antarct. J. U.S. 9: 304-306

Dearborn, J. H., Ferrari, F. D., Edwards, K. C. (1986). Can pelagic aggregations cause benthic satiation? Feeding biology of the antarctic brittle star Astrotoma agassizil (Echinodermata: Ophiuroidea). Antarct. Res. Ser. 44: 1-27

Dearborn, J. H., Watling, L. E., Edwards, K. C., Fratt, D. B., Hendler, G. (1982). Echinoderm biology and general benthic collecting along the Antarctic Peninsula. Antarct. J. U.S. 18: 193-194

DeRidder, C., Lawrence, J. M. (1982). Food and feeding mechanisms: Echinoidea. In: Jangoux, M., Lawrence, J. M. (eds.) Echinoderm nutrition. A. A. Balkema Press, Rotterdam, p. 57-115

Doderlein, L. (1927). Die Seesterne der deutschen Südpolar Expedition 1901-1903. Dt. Südpol. Exp. 1901-1903, 19. Zool. 11: 289-301

Dunbar, M. J. (1970). Ecosystem adaptation in marine polar environments. In: Holgate, M. W. (ed.) Antarctic ecology. Academic Press, London, p. 105-111

Faulkner, D. J. (1993). Marine natural products. Nat. Prod. Rept 10: 497-539

Fell, H. B. (1961). The fauna of the Ross Sea, Part I, Ophiuroidea. N. Z. Dep. Sci. Ind. Res. Bull. 142: 9-79

Fell, F. J. (1976). The cidaroida (Echinodermata: Echinoidea) of Antarctica and the Southern Oceans. Ph.D. thesis, Univ. of Maine, Orono

Ferrari, F. D., Dearborn, J. H. (1989). Second examination of predation on pelagic copepods by the brittle star Astrotoma agassizii. J. Plankton Res. 11: 1315-1320

Fisher, W. K. (1940). Asteroidea. Discovery Rep. 20: 69-306

Fox, L. R., Morrow, P. A. (1981). Specialization: species property or local phenomenon. Science 211: 887-893

Fratt, D. B., Dearborn, J. H. (1984). Feeding biology of the antarctic brittle star Ophionotus victoriae (Echinodermata:
Ophiuroidea). Polar Biol. 3: 127-139

Grime, J. P. (1977). Evidence for the existence of three primary strategies in plants and its relevance to ecological and evolutionary theory. A.m. Nat. 111: 1169-1194

Gutt, J. (1991). Are Weddell Sea holothurians typical representatives of the antarctic benthos? Meeresforsch. 33: 312-329

Harrold, C., Pearse, J. S. (1987) The ecological role of echinoderms in kelp forests. In: Jangoux, M., Lawrence, J M. (eds.) Echinoderm studies, Vol. 2. A. A. Balkema Press, Rotterdam, p. 137-233

Hertz, M. (1927). Die Ophiuroiden der deutschen Südpolar Expedition 1901-1903. Dt. Südpol. Exp. 1901-1903. Zool. 11: $1-56$

Himmelman, J. H. (1984). Urchin feeding and macroalgal distribution in Newfoundland, eastern Canada. Nat. can. 111: $337-348$

Hoshiai, T. (1968). Notes on the sublittoral benthic animals near Syowa Station. Nat. Sci. Mus. (Jap.) 35: 95-100 (in Japanese)

Jangoux, M. (1982). Food and feeding mechanisms: Asteroidea. In: Jangoux, M., Lawrence, J. M. (eds.) Echinoderm nutrition. A. A. Balkema Press, Rotterdam, p. 117-159

Kellogg, D. E., Kellogg, T. B., Dearborn, J. H., Edward, K. C., Fratt, D. B. (1982). Diatoms from brittle star stomachs: implications for sediment reworking. Antarct. J. U.S. 17: $167-169$

Kinne, O. (1963). The effects of temperature and salinity on marine and brackish water animals. Oceanogr. mar. Biol. A. Rev. 1: 301-340

Knox, G. A. (1970). Antarctic marine ecosystems. In: Holgate, M. W. (ed.) Antarctic ecology. Academic Press, Lond, p. $69-96$

Koltun, V. M. (1970). Sponges of the arctic and antarctic: a faunistic review. Symp. zool. Soc. Lond. 25: 285-297

Lares, M. T., McClintock, J. B. (1991) The effects of temperature on the survival, organismal activity, nutrition, growth and reproduction of the carnivorous tropical sea urchin Eucidaris tribuloides. Mar. Behav. Physiol 19: 75-96

Lawrence, J. M., McClintock, J. B. (in press). Energy acquisition and allocation by echinoderms in polar seas: adaptations for success? In: David, B. (ed.) Proc. 8th int. Echinoderm Conf. A. A. Balkema Press, Rotterdam

Littlepage, J. L. (1965) Oceanographic investigations in McMurdo Sound. Antarctic Res. Ser. 5: 1-37

Madsen, F. J. (1961). On the zoogeography of the abyssal fauna in view of knowledge of the Porcellanasteridae. Galathea Rep. 4: 177-218

Massin, C. (1982). Food and feeding mechanisms: Holothuroidea. In: Jangoux, M., Lawrence, J. M. (eds.) Echinoderm nutrition. A. A. Balkema Press, Rotterdam, p. 43-56

McClintock, J. B. (1985). Avoidance and escape responses of the sub-antarctic limpet Nacella edgari (Powell) (Mollusca: Gastropoda) to the sea star Anasterias perrieri (Smith) (Echinodermata: Asteroidea). Polar Biol. 4; 95-98

McClintock, J. B. (1987). An investigation of the relationship between invertebrate predation and the biochemical composition, energy content, spicule content and toxicity of sponges in the benthic community of McMurdo Sound, Antarctica. Mar. Biol. 94: 479-487

McClintock, J. B., Baker, B. J., Hamann, M. J., Slattery, M., Heine, J. N., Kopitzke, R., Bryan, P. (in press). Homarine as a feeding deterrent in the common shallow-water antarctic lamellarian gastropod Marseniopsis mollis: a rare example of chemical defense in a marine prosobranch. J. chem. Ecol.

McClintock, J. B., Baker, B., Slattery, M., Hamann, M., Kopitzke, R., Heine, J. (1994). Chemotactic tube-foot re- 
sponses of the spongivorous sea star Perknaster fuscus to organic extracts from antarctic sponges. J. chem. Ecol. 20: $859-870$

McClintock, J. B., Heine, J., Slattery, M., Weston, J. (1990). Chemical bioactivity in common shallow-water antarctic marine invertebrates. Antarct. J. U.S. 25: 204-206

McClintock, J. B., Pearse, J. S. (1987). Reproductive biology of the common antarctic crinoid Promachocrinus kerguelensis (Echinodermata: Crinoidea). Mar. Biol. 96: 375-383

McClintock, J. B., Pearse, J. S., Bosch, I. (1988). Population structure and energetics of the shallow-water antarctic sea star Odontaster validus in contrasting habitats. Mar. Biol. 99: $235-246$

McClintock, J. B., Slattery, M., Heine, J., Weston, J. (1992). Chemical defense, biochemical composition and energy content of three shallow-water antarctic gastropods. Polar Biol. 11: 623-629

Miller, K. A., Pearse, J. S. (1991). Ecological studies of seaweeds in McMurdo Sound, Antarctica. Am. Zool. 31: 35-48

Morrison, G. W. (1979). Studies on the ecology of the subantarctic ophiuroid Ophionotus hexactis. M.S. thesis, Queen Mary College, Univ. of London

Mortensen, T. (1936). Echinoidea and Ophuroidea. Discovery Rep. 12: $199-348$

Numanami, H., Kosaka, M., Naito, Y., Hoshiai, T. (1984). Distribution of carnivorous benthic invertebrates in the northeastern part of Lützow-Holm Bay, Antarctica. In: Hoshiai, T., Fukuchi, M. (eds.) Memoirs of the National Institute of Polar Research Special Issue no. 32, Proc. 6th Symp. Polar Biol. National Institute of Polar Research, Tokyo

Pearse, J. S. (1965). Reproductive periodicities in several contrasting populations of Odontaster validus Koehler, a common antarctic asteroid. In: Llano, G. A. (ed.) Biology of the Antarctic Seas, Vol. 2. Antarct. Res. Ser. 5: 39-85

Pearse, J. S. (1969). Antarctic sea-star. Aust. nat. Hist. 16: $234-238$

Pearse, J. S., Giese, A. C. (1966). Food, reproduction and organic constitution of the common antarctic echinoid Sterechinus neumayeri (Meissner). Biol. Bull. 130: 387-401

Pearse, J. S., McClintock, J. B., Bosch, I. (1991) Reproduction of antarctic benthic marine invertebrates: tempos, modes, and timing. Am. Zool. 31: 65-80

Peckham, V. (1964). Year-round Scuba diving in the Antarctic. Polar Rec. 12: 143-146

This review was submitted to the editor
Percy, J. A. (1972). Thermal adaptation in the boreo-arctic echinoid, Strongylocentrotus droebachiensis (O. F. Muller, 1776). I. Seasonal acclimatization of respiration. Physiol. Zool. 45: 277-289

Percy, J. A. (1973). Thermal adaptation in the boreo-arctic echinoid, Strongylocentrotus droebachiensis (O. F. Muller, 1776). II. Seasonal acclimatization and urchin activity. Physiol. Zool. 46: 129-138

Percy, J. C. (1974). Thermal adaptation in the boreo-arctic echinoid, Strongylocentrotus droebachiensis (O. F. Muller, 1776). IV. Acclimation in the laboratory. Physiol. Zool. 47: $163-171$

Picken, G. B. (1985). Benthic research in Antarctica: past, present and future. In: Gray, J. S., Christiansen, M. E. (eds.) Marine biology of polar regions and effects of stress on marine organisms. Wiley, Chichester, p. 167-183

Pyke, G. H. (1984). Optimal foraging theory: a critical review. A. Rev. Ecol. Syst. 15: 523-575

Sloan, N. A. (1980). Aspects of the feeding biology of asteroids. Oceanogr. mar. Biol. A. Rev. 18: 57-124

Smith, G. A., White, D. C., Nichols, P. D. (1986). Antarctic benthic and sea-ice microalgal interactions: food chain processes and physiology. Antarct. J. U.S. 21: 174-175

Stockton, W. L. (1984). The biology and ecology of the epifaunal scallop Adamussium colbecki on the west side of McMurdo Sound Antarctica. Mar. Biol. 78: 171-178

Vadas, R. L. (1977). Preferential feeding: an optimization strategy in sea urchins. Ecol. Monogr. 47: 337-371

Valentine, J. W. (1983). Seasonality: effects in marine benthic communities. In: Tevesz, M. J. S., McCall, P. L. (eds.) Biotic interactions in recent and fossil benthic communities. Plenum Press, New York, p. 121-156

Warner, G. (1982). Food and feeding mechanisms: Ophiuroidea. In: Jangoux, M., Lawrence, J M. (eds.) Echinoderm nutrition. A. A. Balkema Press, Rotterdam, p. $161-184$

White, D. C., Smith, G. A., Guckert, J. B., Nichols, P. D. (1993). Nearshore benthic marine sediments. In: Friedmann, E. I. (ed.) Antarctic microbiology. Wiley-Liss, Inc., New York, p. $219-240$

Zamarano, J. H., Duarte, W. E., Moreno, C. A. (1986). Predation upon Laternula elliptica (Bivalvia: Anatinidae): a field manipulation in South Bay, Antarctica. Polar Biol. 6: $139-143$

Manuscript first received: January 13, 1994

Revised version accepted: May 18, 1994 